\title{
Transport Infrastructure and Regional Convergence: a Spatial Panel Data Approach
}

\author{
Xavier Fageda (University of Barcelona) \\ Cecilia Olivieri (Universidad de la República, Uruguay)
}

\begin{abstract}
This article examines the contribution of transport infrastructure to regional convergence in Spain for 1980-2008. We employ spatial econometric techniques that decompose the direct, indirect and total effects of roads, railways, ports and airports. In addition, it complements the analysis by estimating the determinants of the regional allocation of transport investments. The evidence confirms the presence of absolute and conditional convergence. However, only roads appear to have an impact on this convergence process. We also find that the main driver of transport investments has been to equalize the infrastructure endowment between the different Spanish regions. The reduction of inequalities between regions in terms of road provision could explain the positive contribution of roads to the process of regional convergence in Spain.
\end{abstract}

JEL classification: O18, R11, R12, R53, R58

Keywords: Regional Convergence, Transport Infrastructure, Spatial econometrics, Spain 


\section{Introduction}

Economic growth and changes in regional disparities over time have been traditional concerns of scholars in the field of economics. As a result, several empirical and theoretical approaches have been developed to examine the regional convergence process (see, among others, Baumol, 1986, Barro and Sala-i-Martin, 2004 and Canaleta et al., 2004). Likewise, international organisations have given their backing to public infrastructure investment as a key mechanism for reducing gaps between lagging and leading regions. Indeed, according to the World Bank Report (2009), the greater mobility of the production factors promoted by these policies makes infrastructure investment a necessary element in any development strategy.

Spain is a paradigmatic example of a country with wide regional disparities. In pursuing regional convergence, the massive allocation of resources has seen the country expand its infrastructure capacity, so that at present it is the European country with the most extensive motorway and high-speed railway networks (Albalate et al., 2015). Against this backdrop, the positive impact of transport infrastructure on Spain's process of convergence would seem to be a relevant hypothesis to test.

To this point, several studies have examined the role of transport infrastructures in regional convergence. It is generally accepted that transportation contributes to economic growth, but their influence on reducing regional economic inequalities is less clear.

Studies that use samples of several countries generally find a positive effect of surface transportation on regional convergence. Calderón and Chong (2004) use country-level data to show that the endowment of roads and railways (in terms of both quantity and quality) are negatively linked with income inequality. Del Bo and Florio (2012) find a positive effect of motorways on regional convergence using data of regions within the European Union. Lesssmand and Seidel (2017) use luminosity data to examine the determinants of regional inequality for a sample of countries from all over the world. They use gasoline prices and country size as proxies for transportation costs and find that increasing transport costs increase regional inequality in large countries. 
However, studies that use regional data within a country generally do not find evidence about a positive influence of transport infrastructures on regional convergence. Some works do not explicitly test for regional convergence but their analysis have implications on the role of transportation in reducing regional disparities. Costa-Font and Rodríguez-Reggia (2006) investigate the contribution of public investments in infrastructures to the reduction of regional inequalities in México. By means of a quantile regression, they find that public investments have only been able to reduce regional inequalities among the richest regions. In a similar vein, Pereira and Andratz (2006) estimate vector autoregressive (VAR) models for each region in Portugal and they find that public investments in transportation has contributed to the concentration of the activity in Lisbon. Finally, Baum-Snow et al. (forthcoming) analyze the effects of the recently constructed Chinese national highway system on regional outcomes. They find that highways that improve the access to local markets lead to an economic output and population increase in regional primates at the expense of hinterland prefectures, while that highways that improve the access to international ports promote growth of hinterland prefectures.

Some other works analyze the regional convergence process within a country and the role of transportation in such process. Checherita (2009) shows that the regional convergence process in United States is not explained by the stock of public capital in each State. Rodríguez-Pose et al. (2012) develop a spatial econometric model to show that public investments in transport infrastructures has not contributed to the regional convergence in Greece. Cosci and Mirra (2018) analyze the role of highways on the regional convergence in Italy using a spatial econometric model. Their results suggest that motorways may have contributed to reduce regional disparities in some periods but the opening of the Autostrada del Sole has just contributed to the economic growth of the richer regions located in the centre-north.

In this paper, we add to this literature by examining the role of different types of transport infrastructures on regional convergence in Spain. We provide evidence of the conditional and unconditional convergence processes undergone by the Spanish provinces between 1980 and 2008 .

As in the studies of Rodríguez-Pose et al. (2012) and Cosci and Mirra (2018), we exploit spatial econometric techniques and apply a spatial Durbin model (SDM) to measure the effects on the region in which the investment is made and the spillover effects in neighbouring regions. In this 
regard, we examine the direct, indirect and total impacts of roads, railways, ports and airports. This disaggregation in different types of transport infrastructures is a novelty with respect to previous studies on the contribution of transport infrastructures to regional convergence. Indeed, they usually use an aggregate indicator of the investment or the stock of transport infrastructure and only in some cases does attention focus on the role of roads.

Furthermore, we analyse the main drivers of the regional distribution of investments in transportation during the considered period. In particular, we examine whether investments have been guided by efficiency, redistribution and/or equity concerns. This policy equation may provide an explanation of the contribution of transport infrastructures to regional convergence. We could expect that the contribution of transport infrastructures to regional convergence is modest in case that redistribution or equity concerns are not guiding the regional allocation of investments by the central government.

In this regard, a number of studies have analysed the determinants of the regional allocation of investment in transportation, focusing on the equity-efficiency trade-off and the role played by political factors (Yamano and Ohkawara, 2000; Castells and Solé-Ollé, 2005; Cadot et al., 2006; Golden and Picci, 2008; Kemmerling and Stephan, 2002, 2008; Albalate et al., 2012; Monastiriotis and Psycharis, 2012). Hence, we provide a bridge between the literature that examines the role of transportation in the regional convergence process and the literature that studies the factors that account for the regional allocation of investment in transportation.

We find that the Spanish provinces converge to a common steady-state level that could be indicative of an automatic tendency toward the equalisation of income. Furthermore, the endowment of transport infrastructures does not appear to play a substantial role in the regional convergence process. However, the positive direct effect of roads on economic growth may have contributed to an intensification of the regional convergence in Spain. Results of the policy equation suggest that investments have been guided by an equity concern in the sense of equalizing the transport infrastructure endowment between the Spanish provinces. This could explain the positive effect of roads on regional convergence, although we also find that regions with a higher level of per capita income have received more investments. 
The remainder of this study proceeds as follows. Section 2 provides a detailed description of the literature. Section 3 reports Spanish transport investment data. Section 4 describes the variables included in the analysis and their data sources. Section 5 presents the empirical specification of the models and the econometric approach. Section 6 reports the results, and finally, in section 7 we present our conclusions and discuss the policy implications of our findings.

\section{Literature review}

The economic impact of transport infrastructure has been extensively studied in the literature with analyses falling into three main streams: the impact of transportation on economic growth, the factors that determine investment across regions and the identification of a relationship between infrastructure and regional convergence. The analysis undertaken herein specifically seeks to address these last two questions; however, in discussing our findings the close interrelations between all three questions become evident.

Regarding the first issue, many empirical studies seek to estimate production functions to determine the impact of aggregate amounts of public capital on economic growth. They include Aschauer (1989), Munnell (1990), Garcia-Milà and McGuire (1992) and Holtz-Eakin (1994). Other studies undertake their analyses using cost functions (Nadiri and Mamuneas, 1994; Morrison and Schwartz, 1996). Some recent contributions to this question have employed different theoretical frameworks to capture the spatial externalities of transport infrastructure (Cohen, 2010; Del Bo and Florio, 2012; Crescenzi and Rodríguez-Pose, 2012; Yu et al., 2013; Chen and Haynes, 2015; Lo Cascio et al., forthcoming). In general, their results point (albeit not unanimously) to a direct and positive impact. However, these new econometric techniques suggest that the magnitude of the effect is not as great as that reported in the pioneering work of Aschauer, although the question is still under debate.

For the specific case of Spain, several studies have analysed the impact of transport infrastructures considering the possible existence of spatial spillovers. Álvarez et al. (2006) report positive direct effects of the stock of public capital while evidence of indirect effects was inconclusive. Baños et al. (2013) obtained the same results when studying the impact of better road accessibility on the private sector. Gomez-Antonio and Fingleton (2012) evidenced positive direct effects but negative spillovers from the change in capital stock over neighbouring provinces. 
Likewise, Delgado and Álvarez (2007), in a specific study of high capacity road endowments, and Moreno and López-Bazo (2007) demonstrated that transport infrastructure has a positive direct effect but a negative spillover effect for other provinces. The latter authors also found that returns to local public capital are higher than those of transport infrastructure, in line with Gómez-Antonio and Garijo (2012). Finally, Arbués et al. (2015) find positive direct and indirect effects of roads and negative direct effects of ports.

With only a few exceptions (Arbués et al., 2015; Chen and Haynes, 2015; Lo Cascio et al., forthcoming), the analysis is made without any prior disaggregation by type of infrastructure. In this regard, different studies found a positive impact of a specific transportation mode on some measure of regional or urban economic performance. Relevant examples of this literature include Agrawal et al. (2017), Blonigen and Cristea (2015), Bottasso et al. (2013), Donaldson (2018), Duranton (2016), Duraton and Turner (2012), Möller and Zierer (2018), Percoco (2016) and Xu and Nakajima (2017). Any of these previous studies is aimed to examine the contribution of transport infrastructures to regional convergence that is the main goal of our analysis.

The second stream analyses the political decision-making process behind regional transportation investment. Most studies on this subject focus on the three normative principles of infrastructure investment allocation across regions: that is, efficiency, redistribution and equity. The so-called "trade-off between efficiency and equity" implies that, in general, one of these objectives is in conflict with the others. According to this research (Yamano and Ohkawara, 2000; Kemmerling and Stephan, 2002, 2008; Monastiriotis and Psycharis, 2014), the efficiency criterion means spending in regions where the marginal productivity of infrastructure is highest; redistribution means promoting the development of poorer regions by means of infrastructure investment; and, equity seeks to target investment in regions with the lowest infrastructure endowment.

Among the empirical studies, Yamano and Ohkawara (2000) examine the effects of public infrastructure investment on Japan's regional production structure and conclude that if the government had adopted a policy guided by goals of efficiency, the level of production would have been greater than that experienced by pursuing equity. In the same line, De la Fuente (2004) argues against the regional policy applied by the EU, in which resources are allocated directly to public investment in infrastructure to improve the productive capacity of the less developed regions. 
Among EU countries, in a study of transportation infrastructure in Spain, Castells and Solé-Ollé (2005) conclude that regional governments seem to be more inclined towards efficiency than are central governments; whereas, in an analysis of the functional and spatial allocation of the highly centralised public investment in Greece, Monastiriotis and Psycharis (2014) conclude that the allocation has not been efficient. Kemmerling and Stephan (2008) find that both efficiency and redistribution matter in an analysis for France, Germany, Italy and Spain.

Furthermore, Kemmerling and Stephan (2002) for Germany, Castells and Solé-Ollé (2005) for Spain, Golden and Picci (2008) for Italy and Cadot et al. (2006) for France find that political factors such as electoral competition or electoral rents influence the allocation of public infrastructure investment. Finally, Albalate et al. (2012) and Bel (2011) show that infrastructure policy in Spain responds to the objective of transport centralisation around the capital.

Our contribution to the literature on the determinants of the investments in transport infrastructures is that we link the results of this equation to those obtained in the equation of regional convergence. We could expect that the contribution of transport infrastructures to regional convergence is modest in case that redistribution or equity concerns are not guiding the regional allocation of investments by the central government.

Finally, the third stream focuses on the somewhat controversial issue of the regional convergence process. As we have mentioned above, empirical studies of the role of public infrastructure on convergence provide conflicting results. Cross-country analyses show a positive impact of transport infrastructures on regional convergence (Calderón and Chong, 2004; Del Bo and Florio, 2012; Lesssmand and Seidel, 2017). In contrast, regional analysis within a country usually does not find evidence of a relevant contribution of transportation on such regional convergence (Costa-Font and Rodríguez-Reggia, 2006; Pereira and Andratz, 2006; Checherita, 2009; Rodríguez-Pose et al., 2012; Cosci and Mirra, 2018, Baum-snow et al., forthcoming).

Our contribution to this previous literature on transport infrastructures and regional convergence is that we disaggregate the analysis for different types of transport infrastructures (roads, railways, airports, ports). ${ }^{1}$ Furthermore, we estimate an equation for the determinants of public investments in transport infrastructures to provide an explanation of our results for the

\footnotetext{
${ }^{1}$ Unfortunately, our data do not allow us to dissagregate data between diferent types of roads.
} 
contribution of transportation to regional convergence. We also estimate a spatial econometric model as it has been made in just two previous studies (Rodríguez-Pose et al., 2012; Cosci and Mirra, 2018).

Finally, there is a growing literature that is somehow connected to the role of infrastructures in reducing economic inequality between territories. Indeed, several studies show the role of roads in promoting processes of suburbanization or decentralization of population and economic activity within an urban area (Baum-Snow, 2007; Baum-Snow et al., 2017; Garcia-López et al., 2015). However, note that our focus is on economic inequality between regions while these studies focus on inequalities within an urban area.

\section{Investment in transport infrastructure in Spain}

Spain has substantially expanded its transport infrastructure over the period studied here. Figure 1 shows the evolution of transport investment at the national level disaggregated into roads, railways, airports and ports. It also shows the evolution of the gross domestic product (GDP) on the right axis. As can be seen, at the beginning of the 1980s, the Government's transport investment policy was targeted at increasing the capacity of the roads, in order to endow the country with highcapacity motorways. From that date until the end of the 1990s, investment policy stressed the strengthening of the political centre, by constructing a 200-kilometre belt around Madrid and by increasing the connections of the centre with the periphery (Albalate et al., 2012).

In recent decades, Spain's transport investment policy has shifted its attention from roads to high-speed railways, based on the expansion of the number of destinations and targeted almost exclusively at passenger transport.

The financing schemes for transport infrastructure have not been the same; thus, high capacity network modes (roads, railways) receive the largest share of Spanish transport infrastructure investment, while single transport facilities (ports, airports) have received a smaller allocation of resources (see Figure 1). Having said that, airport investment in Spain has been much higher than that in other European Union (EU) air markets. 
The regional allocation of investment in network (roads, railways) and single facilities (ports, airports) at the beginning and the end of the period is shown in Figures 2 and 3. The figures show that investment in network modes has been allocated mainly in the north of the country, although it has increased throughout the rest of the territory as well. At the same time, investment in single facilities predominates along the Atlantic and Mediterranean coasts; yet, at the end of the period, an increase in investment is recorded in other regions inside the country.

The policies implemented have enabled Spain to become the EU country with the most extensive motorway network and to develop the most extensive high-speed railway network in Europe (Albalate et al., 2015). Moreover, according to data provided by the International Transport Forum (cited in Albalate et al., 2015), over the period 2000-2009, airport investment in Spain was also high - 1.5 times greater than that in Germany, 1.9 times higher than that in France and 4.8 times greater than the corresponding investment in Italy. The figures for investment in ports tell a similar story. The data indicate that between 2000 and 2009, investment in Spanish ports doubled that made in Italy, and was three times higher than the German budget and six times higher than the French budget.

\section{Data and variables}

For the purpose of this study, we constructed a panel of Spanish regions using annual data for the period 1980-2008. We consider all of Spain's provinces, with the exception of the islands and the autonomous cities of Ceuta and Melilla owing to differences in the endowment of their transport infrastructure and the difficulties in capturing their indirect effects.

The data were provided by the Instituto Valenciano de Investigaciones Económicas (Valencian Institute of Economic Research, IVIE) and Spain's Instituto Nacional de Estadísticas (National Institute of Statistics, INE). The former provided data on investment, net capital stock and employment while the second supplied information on GDP, population and surface area. The spatial unit of analysis is the EU regional level classification NUTS3 (Nomenclature des Unités Territoriales Statistiques), which in the case of Spain corresponds to the provinces. 
The dependent variable in the analysis of the regional convergence process is the regional growth rate of per capita GDP $\left(\Delta \mathrm{GDP}_{i, t 0+T}\right)$, computed as the difference between the logarithm of the per capita GDP of province $i$ in period $t_{0+T}$ and the logarithm of the per capita GDP of province $i$ in period $t 0$. The main descriptive statistics of this variable, for each province and the entire period, are given in Table 1. Note that in the analysis of the role played by transport infrastructure in regional convergence, we consider the per capita regional income and the interregional public stock of infrastructures, disaggregated into roads, railways, ports and airports. According to the data source, the estimation procedure of the net capital stock is the perpetual inventory method (see Table 2 for the descriptive statistics). Finally, in the analysis of the determinants of investment in transportation, the dependent variable is the regional growth rate of the total stock in transport infrastructure $\left(\Delta \operatorname{Transport}_{i, t 0+T}\right)$, computed as the difference between the transport stock in province $i$ in period $t_{0+T}$ and the transport stock in province $i$ in period $t_{0}$.

Our data show geographical inequalities in the distribution of per capita GDP across the Spanish provinces. Figure 4 shows the evolution, focusing on four specific years during the period studied: 1980, 1990, 2000, and 2008. As can be seen, the richer provinces are situated in the northeast of the country, whereas the poorer provinces are in the southwest. This distribution pattern is largely maintained over the period. Figure 5 shows the distribution of per capita GDP

growth between 1980-1990, 1990-2000 and 2000-2009. In this case the distribution pattern is less clear, although it can be seen that the fastest growing areas are those with the lowest per capita GDP.

Figure 6 depicts a dispersion graph for the whole sample. The annual growth rate of per capita GDP is on the $y$-axis and the initial level of output on the x-axis. A negative relationship can be seen between the two variables, which is indicative as to the validity of the convergence hypothesis.

\section{The Empirical strategy}

\subsection{Regional convergence and transport infrastructure}


In this study, we seek to validate the hypothesis that there has been a process of economic convergence between Spain's provinces in the period 1980-2008. Complementary to this, we also seek to verify the hypothesis that transport infrastructure plays a significant role in accounting for regional convergence.

Economic convergence at the country or regional level refers to an inverse relationship between the growth rate of per capita income and the starting level of per capita income. Specifically, it is a situation where the gap in per capita output between regions tends to decrease over time.

Empirically, the most frequently employed model of convergence is the " $\beta$-convergence model" developed in Barro and Sala-i-Martin (1992a) and Sala-i-Martin (1996). Within this framework, the process by which poor regions grow faster than their richer counterparts in the transition to the steady-state is measured by the $\beta$ coefficient of the estimated regression. There is evidence of convergence if $\beta$ is negative and statistically significant.

Overall, we conduct a panel data analysis to consider both the cross-sectional and time series dimensions of the processes. Additionally, the analysis included a spatial panel data specification, in order to capture potential externalities. We applied the Moran's I test as an indicator of spatial autocorrelation. The index indicated the presence of significant spatial autocorrelation in the models, supporting the inclusion of spatial factors.

Three main models have been proposed in the spatial econometrics literature. The spatial Durbin model (SDM) controls for endogenous spillovers, including the spatially lagged dependent variable, and for exogenous spillovers, using spatial lags in the regressors. In contrast, the spatial autoregressive model (SAR) only includes a spatially lagged dependent variable, while the spatial error model (SEM) contains a spatially correlated error component.

The decision as to which spatial model to select is governed by the specific research goals and the context in which the model is to be applied (Lesage and Fisher, 2008; Lesage and Pace, 2009). Here, eventual selection of the model specifications was driven by Wald and likelihood ratio test results; the former indicated the greater suitability of the SDM compared to that of the SAR, while the latter rejected the SEM as unsuitable. Furthermore, the SDM actually contains the other two 
models and has the attribute of giving unbiased estimates, even if the true economic process is SAR or SEM (Elhorst, 2010).

In the specific context of the study conducted here, the implication is that the economic performance of a particular region is dependent, to some degree, on the value that the variable assumes in neighbouring areas. It is this dependence that justifies the inclusion of a spatially lagged dependent variable. Moreover, a change in an independent variable for a particular province potentially affects the economic activity in all the other provinces.

Indeed, the literature presents evidence of the fact that better transport infrastructures in a region may have an impact on neighbouring regions, thus permitting the inclusion of spatially lagged explanatory variables. A positive effect means that a particular region benefits from the better endowment of its neighbours, while a negative effect indicates that the region is left worse off.

In the first stage of the empirical strategy, we tested the unconditional $\beta$-convergence hypothesis. To do so, we performed an unconditional convergence estimation using the whole sample of 47 provinces, with the annual growth rate of per capita GDP as the endogenous variable and the initial level of per capita GDP (in logs) as the explanatory variable.

The specification of the SDM model, for the corresponding province $i$ in year $t$, is as follows:

$$
\Delta G D P_{i t+1, t}=\rho W\left(\Delta G D P_{i t+1, t}\right)+\beta \ln \left(G D P_{i t}\right)+\gamma W \ln \left(G D P_{i t}\right)+\mu_{i}+\epsilon_{i t}
$$

In the second stage, we examined the role played by transport infrastructure in regional growth. We applied a similar procedure to that of absolute convergence, but in this case we included the disaggregation by type of transport infrastructure:

$$
\begin{gathered}
\Delta G D P_{i t+1, t}=\rho \mathrm{W}\left(\Delta G D P_{i t+1, t}\right)+\beta \ln \left(G D P_{i t}\right)+\gamma_{1} \ln \left(\text { Roads }_{i t}\right)+\gamma_{2} \ln \left(\text { Railways }_{i t}\right)+ \\
\gamma_{3} \ln \left(\text { Airports }_{i t}\right)+\gamma_{4} \ln \left(\text { Ports }_{i t}\right)+\gamma_{5} W \ln \left(G D P_{i t}\right)+\gamma_{6} W_{\ln }\left(\text { Roads }_{i t}\right)+\gamma_{7} W \ln \left(\text { Railways }_{i t}\right)+ \\
\gamma_{8} W \ln \left(\text { Airports }_{i t}\right)+\gamma_{9} W \ln \left(\text { Ports }_{i t}\right)+\mu_{i}+\epsilon_{i t}
\end{gathered}
$$


In equation 2, we add the net stock of roads, railways, airports and ports (in logs) as explanatory variables. Note that in equations 1 and 2 we include the spatially lagged dependent variable and the spatially lagged explanatory variables.

In equations 1 and 2, $\mu_{i}$ are individual fixed effects and $\mathrm{W}(\mathrm{N} \times \mathrm{N})$ are the spatial weights matrices which summarise the arrangements of the $\mathrm{N}$ spatial units in the sample. In general, the literature does not recommend using the random effects model for estimates of this type (Elhorst, 2012b). In addition, the fixed effects model allows us to control for omitted variables that correlate with the dependent variables and which are invariant over time. In this respect, the fixed effects model only captures the variation within the data.

Each element of $\mathrm{W}$ is referred to as the spatial weight, $\mathrm{w}_{\mathrm{ij}}$. The spatial weights capture the neighbourhood effect and differ from zero when regions $i$ and $j$ are neighbours. By convention, no region can be a neighbour of itself, so all the elements in the main diagonal of $\mathrm{W}$ are equal to zero $\left(\mathrm{w}_{\mathrm{ii}}=0\right)$.

The spatial weights matrix occupies a central position in spatial econometrics as it defines the set of neighbours for each location. However, one weakness that has been attributed to spatial econometric models is that the choice of the weights matrix influences the rest of the analysis (Elhorst, 2010). In practice, the weight matrix is constructed using different criteria. These criteria range from the use of the geographical location to the use of flows that capture social interactions and other sources of socio-economic information. The geographical criterion has the advantage of being exogenous to the model, since the choice of neighbours, as Anselin $(1988,2001)$ points out, does not respond to variables considered in the analysis.

Once the spatial weights have been selected, it is usual to work with a transformation to improve the statistical properties of the estimators and contrasts. We applied the row-standardisation that is the most commonly employed.

We estimated an SDM with three different specifications of the spatial weight matrix: a standardised contiguity matrix, a standardised inverse matrix of the squared distance and the fivenearest-neighbours matrix. First, we considered a row-standardised contiguity matrix 
(W_contiguity) with elements $\mathrm{w}_{\mathrm{ij}} \neq 0$ when two provinces share a common border and $\mathrm{w}_{\mathrm{ij}}=0$ otherwise. This matrix assumes that interregional effects are present only between bordering provinces. Second, we computed a row-standardised inverse matrix of the squared distance (W_distance), based on the geographical location of the provincial capitals. The assumption behind this specification is that all regions contribute to spatial spillovers according to their respective distances between each other, the greater distances being penalised more heavily. Finally, in order to check the robustness of the results, we constructed a row-standardised fivenearest-neighbours matrix (W_nearestn), in which the elements $\mathrm{w}_{\mathrm{ij}} \neq 0$ are the five nearest provinces. In this case, we relax the assumptions made with regard to the first matrix, and include more elements in the interactional space.

The spatial lags included in the regression model introduce difficulties in the interpretation of the estimates. In order to measure and accurately interpret this spatial connectivity, a methodology has been proposed (for a deeper and more exhaustive discussion see LeSage and Fisher, 2008). When analysing the results, the total effect of a change in an explanatory variable of a region can be decomposed into a 'direct effect' and an 'indirect effect'. The direct effect captures the impact on the region itself, accounting for the feedback influences that arise as a result of the regional interconnection. The indirect effect is that associated to the impact on other regions, the spatial spillovers and the feedback influences. The sum of the direct effect and the indirect effect gives the 'total effect'.

Overall, the expected signs of the spatially lagged variables are unclear. In spatial growth models, the spatial dependence parameter $(\rho)$ is expected to be positive and less than unity, indicating that regional growth rates are positively related to those from neighbouring regions (LeSage and Fisher, 2008). In the case of network infrastructures (roads, railways) a positive effect may perhaps be found reflecting the better connectivity provided by improved road and railway links beyond the specific region in which the investment was made. However, the effect might also be negative due to the fact that better infrastructure may attract the productive factors from other regions. In the case of single infrastructures (ports, airports), the provinces situated closest to well-endowed regions may benefit from easier access to a wider range of goods from distant 
markets, while provinces with large ports and/or airports may also attract productive factors from neighbouring regions without such infrastructure.

Finally, it is worth mentioning that, in all the specifications, we rejected the null hypothesis that the SDM could be simplified to the spatial lag model or to the SEM. Indeed, the spatial autocorrelation coefficient $\left(\mathrm{W}\left(\Delta G D P_{i t+1, t}\right)\right)$ is significant in all specifications, which provides evidence of the fact that Spanish provinces are spatially interconnected. Finally, we computed the Hausman test for all specifications to select between fixed and random effects. In all cases, the fixed effects model was shown to be more suitable for our spatial panel models.

\subsection{Determinants of investment in transport infrastructure}

We also analyse the determinants of transport infrastructure investment. To do so, we use a policy equation that include similar explanatory variables as in previous studies. Our interest in this equation is to provide an explanation of the results for the regional convergence equation. In particular, we want to examine whether efficiency, redistribution and/or equity have been major drivers in the regional allocation of investments in transport infrastructures.

In line with Yamano and Ohkawara (2000), Kemmerling and Stephan (2002, 2008) and Monastiriotis and Psycharis (2014), efficiency imply to invest in regions where the marginal productivity of the stock of capital is higher. Redistribution imply a positive discrimination toward lagging regions so that we should expect a negative relationship between investments and income. Equity imply reducing inequalities between regions in terms of infrastructure endowment. Thus, regions with a lesser endowment of transport infrastructures would receive more investments. Note that we should expect a modest contribution of transport infrastructures to regional convergence if redistribution and/or equity have not driven regional investments in transport infrastructure of the central government.

All previous studies also include political variables related with electoral competition or electoral rents. For consistency with these previous studies, we include two control variables related to electoral competition although they are not essential for our analysis. 
The policy investment equation to estimate is as follows:

$$
\begin{gathered}
\Delta \text { Transport }_{i t+1, t}=\alpha+\rho \Delta \text { Transport }_{i t, t-1}+\beta_{1} \ln \left(\text { Efficiency }_{i t}\right)+\beta_{2} \ln \left(\text { Redistribution }_{i t}\right)+ \\
\beta_{3} \ln \left(\text { Equity }_{i t}\right)+\beta_{4}(\text { Partisan strongholds })_{i t}+\beta_{5}\left(\text { Political congruence }_{i t}+\mu_{t}+\epsilon_{i t}\right.
\end{gathered}
$$

In the above equation, $\mu_{t}$ are year dummy variables. The other variables included are the following:

- Efficiency. This principle implies that investment should be made in provinces where it can be expected to have a high impact on growth: the higher the productivity, the greater the efficiency in any given region. Efficiency is measured as the ratio between regional GDP and total stock of transport infrastructure in a region. Thus, we expect the estimated coefficient of this variable to be positive if efficiency is a goal in the regional allocation of investments in transport infrastructure. This variable has also been considered in the studies of Yamano and Ohkawara (2000), Kemmerling and Stephan (2002, 2008), Cadot et al. (2008) and Monastiriotis and Psycharis (2014).

- Redistribution. This principle of regional policy is based on the use of transport infrastructure to promote the development of poorer regions. We define it as GDP divided by the employed population in the respective province. The estimated coefficient of this variable is expected to be negative if redistribution is a goal in the regional allocation of investments in transport infrastructure. This variable has also been considered in the studies of Yamano and Ohkawara (2000), Kemmerling and Stephan (2002, 2008), Golden and Picci (2008), Albalate et al. (2012) and Monastiriotis and Psycharis (2014)

- Equity. This principle holds to the idea of equalize the infrastructure endowment between regions. It is measured as the total transport infrastructure stock over the size of the province in square kilometres. The estimated coefficient of this variable is expected to be negative if equity is a goal in the regional allocation of investments in transport infrastructure. This variable has also been considered in the studies of Yamano and Ohkawara (2000), Kemmerling and Stephan (2002, 2008), Albalate et al. (2012) and Monastiriotis and Psycharis (2014). 
- Partisan strongholds and Political congruence. From a political point of view, this theory holds that investment is likely to be higher in provinces where the central government party has greater support among the population or in those provinces where the regional and national governments have greater affinity. We use the percentage of votes obtained in each province by the central government party at the general elections as a proxy for this first variable. Likewise, we measure political congruence with a dummy variable that takes a value of one when the regional party is the same as that in central government. We expect the estimated coefficients to have a positive sign.

In this context, the main motivations of the estimation strategy are the control of endogeneity and efficiency. The panel data methodology first considered best suited to growth rate empirical models was the first-difference generalised method of moments (GMM) developed by Holtz-Eakin et al. (1988) and Arellano and Bond (1991). This involves the assumption of no serial correlation of time-invariant disturbances in the original equation in levels (Caselli et al., 1996; Forbes, 2000; Levine et al., 2000). Bond et al. (2001) identified some problems in the effectiveness of this method in empirical growth models using small samples, especially when the variables show persistence over time. By way of solution, they proposed the GMM system estimator (Arellano and Bover, 1995; Blundell and Bond, 1998).

In our sample, however, persistence does not seem to be a major problem and so we have opted to apply the first-difference GMM estimator. Given this assumption, the GMM estimator should be consistent even in the presence of measurement errors and endogenous explanatory variables (Di Giacinto and Espósito, 2012). Moreover, the validity of the instruments can be tested using the Hansen test of overidentifying restrictions.

However, it is worth noting that, while the GMM estimator has the advantage of eliminating any problems of endogeneity, it has the disadvantage of not allowing the heterogeneity between regions to be incorporated when it is not captured by the explanatory variables, whereas the other estimators do. 
As explained previously, and following the state of the art on this specific issue, we performed the first-difference GMM technique, considering as endogenous variables the lag of investments and regional GDP.

\section{Results}

The empirical analysis is presented in three sub-sections. Sub-section 6.1 presents our empirical results for the absolute $\beta$-convergence process in terms of annual growth rates. In sub-section 6.2, we allow for the possibility of multiple steady states and seek to verify the conditional $\beta$ convergence hypothesis, taking into account different components of public stock of transport infrastructure. Our main concern in this section is to determine the contribution of regional public transport endowment to the Spanish provinces' growth rates and to test the extent to which transport infrastructure is influencing the convergence process. Finally, sub-section 6.3 assesses the drivers of investments in transport infrastructure across regions to provide an explanation of their contribution to regional convergence.

\subsection{Absolute $\beta$-convergence}

Table 3 reports the results of the absolute convergence estimation of the bias-corrected SDM model $^{2}$ using the contiguity, distance and nearest neighbour weights matrices, respectively. We find that the signs and significance levels are consistent across the three specifications, although the coefficients differ. Focusing on our variable of interest, the empirical evidence suggests the presence of an absolute convergence process between the Spanish provinces over the period. The $\beta$-coefficient, that is, the estimated parameter of the initial level of per capita GDP is negative and statistically significant for all specifications. Due to similar levels of technology, factor mobility and regulations, this process is more likely among homogeneous regions, mostly in the case of provinces within the same country. Having said this, results are in line with Checherita (2008) for US states, Del Bo et al. (2010) and Del Bo and Florio (2012) for European regions, and Lessman

\footnotetext{
${ }^{2}$ We applied the maximum likelihood (ML) estimator to fit the spatial panel data models, as suggested by Anselin (1988). The ML estimation is based on the assumption of normal error terms, and is implemented in the xsmle stata command.
} 
and Seidel (2017) for worldwide regions. In contrast, Rodríguez-Pose et al. (2012) do not find evidence of absolute convergence for Greek regions.

In order to obtain a preliminary idea of the spatial interactions, Table 3 also notes that, as with the spatially lagged independent variable, the annual growth rate of per capita GDP in a province is positively correlated to the initial level of per capita GDP in the neighbouring areas. The magnitude of the spatial spillover effects are provided in Table 4.

The total effect of the initial level of per capita GDP is not significant, unlike the direct and indirect effects (see Table 4). The indirect effect is positive and statistically significant, which means that the independent variable not only contributes to the dependent variable directly but also indirectly through spatial spillovers. Indeed, the contribution of a particular region to the growth rate of the neighbouring areas is positive, whereas the impact on its own per capita GDP growth rate is negative. Likewise, the findings are in line with the $\beta$-convergence hypothesis.

\subsection{Conditional $\beta$-convergence}

Tables 5 and 6 display the estimation results of the conditional convergence (equation 2), which includes the variables of transport infrastructures.

The evidence still points to the presence of a $\beta$-convergence process, even after introducing infrastructure variables in the model. In fact, the direct negative coefficient of the per capita income variable is now higher. Thus, the introduction of the infrastructure variables seems to accelerate the regional convergence process. This is contrary to the general result obtained in previous studies. Indeed, regional analysis within a country usually does not find evidence of a relevant contribution of transportation on such regional convergence (Costa-Font and Rodríguez-Reggia, 2006; Pereira and Andratz, 2006; Checherita, 2009; Rodríguez-Pose et al., 2012; Cosci and Mirra, 2018).

It should be emphasized here that, unlike these previous studies, we disaggregate the analysis for four different types of transport infrastructures: roads, railways, ports and airports. In addition, 
the Spanish case is particular in the sense that investments in transport infrastructure has been much higher than in other countries (Albalate et al, 2012).

Looking at the effects of the stock of infrastructures on the annual growth rate of per capita GDP, we only find a positive and statistical significant direct effect of roads. Such positive effect of roads is in line of that obtained by Delgado and Álvarez (2007), Baños et al. (2013) and Arbués et al. (2015) for Spanish regions. However, their indirect and total effects are not statistically significant.

Furthermore, the direct, indirect and total effects of railways and airports are not statistically significant. Finally, we find a negative direct effect of ports and a modest positive indirect effect. The total effect of ports is not statistically significant.

Hence, the direct positive effect of roads seems to have contributed to the process of regional convergence in Spain. In contrast, the rest of the transport infrastructures have not played an important role in this process.

The lack of statistical significance of the railways variable may perhaps be explained by the great expansion undergone by Spain's high-speed railways in this period, a network that was designed almost exclusively for passenger transport with little support for freight. Indeed, the limited increase in freight rail transport seems to have weakened the capacity of railways to promote regional equality (Albalate et al., 2015).

The direct negative effect of the ports together with the indirect positive effect is in line with Bottasso et al. (2013) and Arbués et al. (2015). Negative externalities associated to this infrastructure, such as congestion on the roads, are concentrated in the region where the port is located. However, the positive effects go beyond the region where the port is located.

Finally, the lack of statistical significant of the airport variable may be explained by the centralized management system in which investments in each airport are not necessarily related to the amount of traffic that such airport is able to generate (Bel and Fageda, 2009). 


\subsection{Determinants of transport infrastructure investment}

This sub-section reports our findings concerning the determinants of transport infrastructure investment, including the set of independent variables described earlier (equation 3). Results are shown in Table 7.

We conducted several tests to ensure a good model fit. More specifically, the Arellano and Bond test did not reject the null hypothesis of no autocorrelation from the second-order autoregressive residuals, so the estimates include this specification. Moreover, the Hansen $\mathbf{J}$ test of overidentifying restrictions accepts the null hypothesis, as did the difference-in-Hansen tests of exogeneity of instrument subsets.

We find that the main driver of the investment policy in transportation by the central government in Spain has been to equalize the infrastructure endowment between the different Spanish regions. Indeed, the regions with the lowest relative endowment of infrastructures have received a greater volume of investments.

The result for the variable of transport infrastructure endowment is above all determined by the provision of roads and railways given the high weight of these two types of infrastructure in the total stock of transport infrastructures. In this regard, the reduction of inequalities between regions in terms of road provision could explain its positive contribution to the process of regional convergence in Spain.

By contrast, interregional redistribution and efficiency do not appear to have been priorities during the period analysed here. Contrary to our expectations, the variable of redistribution is positive and the variable of efficiency presents a negative sign. Hence, investments have been higher in richer regions. Furthermore, they have been higher in regions where the marginal productivity of the stock of capital is lower.

The failure to consider efficiency as an objective of the infrastructure investment policy may explain why we do not find evidence of a significant positive effect of infrastructures on regional economic growth. In a similar vein, the fact that investments have been higher in regions with higher income levels does not help transport infrastructures contribute to regional convergence. 
Only in the case of roads, it seems that the reduction in inequality between regions in terms of endowment may be offsetting the lack of concern for efficiency and redistribution.

\section{Conclusions}

We have used spatial econometric techniques to analyse both the absolute and conditional $\beta$ convergence-type processes, and the policy decision-making process underpinning the regional allocation of investment in transport infrastructure.

We add to previous literature on the link between transport infrastructures and regional convergence by examining the direct, indirect and total impacts of roads, railways, ports and airports. Furthermore, we analyse whether transport investments have been guided by efficiency, redistribution and/or equity concerns to explain the role of transportation on such regional convergence.

Drawing on data from 1980 to 2008, we have found strong evidence of absolute convergence occurring across Spanish provinces. This result also holds when we consider conditional convergence, and take into account the explicit role of transport infrastructure. However, only roads seems to have contributed to the process of regional convergence in Spain. In contrast, the rest of the transport infrastructures have not played an important role in this process. We also find that the main driver of investments has been to equalize the infrastructure endowment between the different Spanish regions. The reduction in inequality between regions in terms of roads endowment could explain its positive contribution to the regional convergence in Spain.

Our findings may contribute to the debate on the distribution of public resources. In Spain, regional policies have been widely promoted by successive governments using investment to equalize the endowment of transport infrastructures. However, massive investment in transport infrastructure does not necessarily contribute to reduce regional disparities. The development of an extensive high-speed rail network and the high amount of resources devoted to ports and airports have not been effective in reducing economic inequalities between Spanish regions. Hence, our results suggest that efficiency and redistribution need to be taken into account in order to achieve the best allocation of public resources. 
A limitation of this study is the use of the stock of capital as the only indicator of the infrastructure endowment that a region has. The use of physical indicators or indicators based on demand could complement the stock of capital to have a more complete measurement of this endowment. Future research may include a more detailed set of infrastructure endowment indicators to further advance the study of the role of transportation in regional convergence.

\section{References}

Agrawal, A., Galasso, A., Oettl, A. (2017). Roads and innovation, The Review of Economics and Statistics, 99, 417-434.

Albalate, D., Bel, G., Fageda, X. (2012). "Beyond the efficiency-equity dilemma: Centralization as a determinant of government investment in infrastructure". Papers in Regional Science, 91(3), 599-615.

Albalate, D., Bel, G., Fageda, X. (2015) When supply travels far beyond demand: Institutional and regulatory causes of oversupply in Spain's transport infrastructure. Transport Policy, 41, 8089.

Álvarez, A., Arias, C., Orea, L. (2006). Econometric testing of spatial productivity spillovers from public capital. Hacienda Pública Española/Revista de Economía Pública, 178(3), 9-21.

Anselin, L., (1988). Lagrange multiplier test diagnostics for spatial dependence and spatial heterogeneity. Geographical analysis, 20(1), 1-17.

Anselin,L. (2001). Spatial econometrics. A companion to theoretical econometrics, 310330.

Arbués, P., Baños, J. F., Mayor, M. (2015). The spatial productivity of transportation infrastructure. Transportation Research Part A: Policy and Practice, 75, 166-177.

Arellano, M., Bond, S. (1991). "Some tests of specification for panel data: Monte Carlo evidence and an application to employment equations". Review of Economic Studies, 58, 277-97.

Arellano, M., Bover, O. (1995) "Another look at the instrumental variables estimation of error components models." Journal of Econometrics, 68, 29-51.

Aschauer, D. (1989). “Is public expenditure productive?” Journal of Monetary Economics, 23(2), 177-200.

Baños, J., González, P., Mayor, M. (2013) "Productivity and accessibility of road transport infrastructure in Spain. A spatial econometric approach”. Working paper, University of Oviedo.

Barro, R.J., Sala-i-Martin, X. (1992) “Convergence”. Journal of Political Economy, April.

Baumol, W. J. (1986). Productivity growth, convergence, and welfare: what the long-run data show. The American Economic Review, 1072-1085. 
Baum-Snow, N., (2007). Did Highways Cause Suburbanization? Quarterly Journal of Economics, 122, 775-805.

Baum-Snow, N., Brandt, L., Henderson, J.V., Turner, M.A., Zhang, Q. (2017). Roads, railroads, and decentralization of Chinese cities, The Review of Economics and Statistics, 99, 435-448

Baum-Snow, N., Henderson, J.V, Turner, M.A., Zhang, Q., Brandt, L. (forthcoming). Does investment in national highways help or hurt hinterland city growth? Journal of Urban Economics, forthcoming.

Bel, G. (2011). "Infrastructure and nation building: The regulation and financing of network transportation infrastructures in Spain (1720-2010)". Business History, 53(5), 688-705.

Bel, G., Fageda, X. (2009), "Preventing competition because of "solidarity": Rhetoric and reality of airport investments in Spain", Applied Economics, 41(22), 2853-2865.

Blonigen, B.A., Cristea, A.D., (2015). "Airports and urban growth, Evidence from a quasi-natural policy experiment". Journal of Urban Economics, 86, 128-146.

Blundell, R., Bond, S. (1998) "Initial conditions and moment restrictions in dynamic panel data models". Journal of Econometrics, 87, 11-143.

Bond, S. R., Hoeffler, A., Temple, J. (2001) "GMM Estimation of Empirical Growth Models" CEPR, Discussion Papers No. 3048.

Bottasso, A., Conti, M., Ferrari, C., Merk, O., Tei, A., (2013). "The impact of port throughput on local employment: Evidence from a panel of European regions". Transport Policy, 27, 32-38.

Cadot, O., Röller, L.H., Stephan, A. (2006) "Contribution to productivity or pork-barrel? The two faces of infrastructure investment". Journal of Public Economics, vol 90: 6-7, 1133-1153.

Calderón, C., Chong, A. (2004). "Volume and Quality of Infrastructure and the Distribution of Income: An Empirical Investigation", the Review of Income and Wealth, 50 (1), 87-106.

Canaleta, C.G., Arzoz, P.P., Garate, M.P. (2004) "Regional economic disparities and decentralisation". Urban Studies, 41, 71-94.

Cantos, P., Gumbau-Albert, M., Maudos, J. (2005). "Transport infrastructures, spillover effects and regional growth: evidence of the Spanish case". Transport reviews, 25(1), 25-50.

Caselli, F., Esquivel, G., Lefort, F. (1996) "Reopening the Convergence Debate: A New Look at Cross-Country Growth Empirics", Journal of Economic Growth, 1(3), 363.

Castells, A., Solé-Ollé, A. (2005). "The regional allocation of infrastructure investment: The role of equity, efficiency and political factors". European Economic Review, vol 49, 1165 - 1205.

Checherita, C. (2009) "Variations on economic convergence: The case of the United States", Papers in Regional Science, 88(2), 259-279.

Chen, Z., Haynes, K. E. (2015). Regional impact of public transportation infrastructure: A spatial panel assessment of the US Northeast megaregion. Economic Development Quarterly, 29(3), 275-291. 
Cohen, J. P. (2010). "The broader effects of transportation infrastructure: Spatial econometrics and productivity approaches". Transportation Research Part E: Logistics and Transportation Review, 46(3), 317-326.

Cosci, S., Mirra, L. (2018). A spatial analysis of growth and convergence in Italian provinces: The role of highways. Regional Studies, 52(4), 516-527.

Costa-Font, J., Rodríguez-Oreggia, E. (2005). "Is the Impact of Public Investment Neutral Across the Regional Income Distribution? Evidence from Mexico, Economic Geography, 81 (5), 305322.

Crescenzi, R., Rodríguez-Pose, A. (2012). "Infrastructure and regional growth in the European Union”. Papers in Regional Science, 91, 487-513.

De la Fuente, A. (2004). "Second-best redistribution through public investment: a characterization, an empirical test and an application to the case of Spain" Regional Science and Urban Economics, 34, 489-503.

Del Bo, C., Florio, M., Manzi, G. (2010). "Regional infrastructure and convergence: growth implications in a spatial framework". Transition Studies Review, 17 (3), 475-493.

Del Bo, C., Florio, M., (2012). Infrastructure and growth in a spatial framework: evidence from the EU regions. European Planning Studies, 20 (8), 1393-1414.

Delgado, M. J., Álvarez, I. (2007). Network infrastructure spillover in private productive sectors: evidence from Spanish high capacity roads. Applied Economics, 39(12), 1583-1597.

Di Giacinto, V., Esposito, L. (2012). "Convergence of financial structures in Europe: an application of factorial matrices analysis," The Financial Systems of Industrial Countries (183215). Springer Berlin Heidelberg.

Donaldson, D., 2018. Railroads of the Raj: Estimating the impact of transportation infras- tructure. Am. Econ. Rev. 108 (4-5), 899-934

Duranton, G. (2016), Determinants of city growth in Colombia, Papers in Regional Science, 95 , 101-132.

Duranton, G., Turner, M.A., 2012. Urban growth and transportation. Review of Economic Studies, 79, 1407-1440.

Elhorst, J.P., (2010). Applied Spatial Econometrics: Raising the Bar. Spatial Economic Analysis. $5(1), 9-28$.

Elhorst, J.P, (2012a). Dynamic spatial panels: Models, methods and inferences, Journal of Geographical Systems 14 (1), 5-28

Elhorst, J.P.. (2012b) Matlab Software for Spatial Panels, International Regional Science Review, doi: 10.1177/0160017612452429.

Elhorst, J. P. (2014). Spatial panel data models. In Spatial Econometrics (pp. 37-93). Springer Berlin Heidelberg. 
Florio, Massimo, ed. Public investment, growth and fiscal constraints: challenges for the EU new member states. Edward Elgar Publishing, 2011.

Forbes, K.J. (2000). "A Reassessment of the Relationship between Inequality and Growth." American Economic Review, 90(4), 869-87.

Garcia-López, M.A., Holl, A., Viladecans-Marsal, E., 2015. Suburbanization and highways in spain when the romans and the bourbons still shape its cities. Journal of Urban Economics, 85, $52-67$

García-Milà, T., McGuire, T. (1992). "The contribution of publicly provided inputs to states' economies". Regional Science and Urban Economics, vol 22, 229-241.

Golden, M. A., Picci, L. (2008). "Pork-barrel politics in postwar Italy, 1953-94". American Journal of Political Science, 52(2), 268-289

Gómez-Antonio, M., Garijo, A. A. (2012). "Evaluating the Effect of Public investment on Productivity Growth Using an Urban Economics Approach for the Spanish Provinces". International Regional Science Review, 35(4), 389-423.

Gómez-Antonio, M., Fingleton, B. (2012). "Analyzing the impact of public capital stock using the NEG wage equation: A spatial panel data approach". Journal of Regional Science, 52(3), 486502.

Holtz-Eakin, D., W. Newey, H.S. Rosen. (1988). "Estimating vector autoregressions with panel data". Econometrica 56, 1371-95.

Kemmerling, A., Stephan, A. (2002). "The contribution of local public infrastructure to private productivity and its political economy: Evidence from a panel of large German cities". Public Choice, 113(3-4), 403-424.

Kemmerling, A., Stephan, A. (2008). "The politico-economic determinants and productivity effects of regional transport investment in Europe". EIB papers, 13(2), 36-60.

LeSage,J., Pace, R.K., (2009). Introduction to Spatial Econometrics. In: CRC Press (eds), Taylor and Francis Group.

LeSage, J., Fischer, M. (2008). "Spatial Growth Regressions: Model Specification, Estimation and Interpretation", Spatial Economic Analysis, 3:3, 275-304.

Lessmann, C., Seidel, A. (2017). Regional inequality, convergence, and its determinants - A view from outer space, European Economic Review, 92, 110-132.

Levine, R.., Loayza, N., Beck, T. (2000) "Financial intermediation and growth: Causality and causes." Journal of Monetary Economics, 46, 31-77.

Lo Cascio, I., Mazzola, F., Epifanio, R. (forthcoming). Territorial determinants and NUTS 3 regional performance: A spatial analysis for Italy across the crisis, Papers in Regional Science, forthcoming.

Möller, J., Zierer, M. (2018). Autobahns and jobs: A regional study using historical instrumental variables, Journal of Urban Economics, 103, 18-33. 
Monastiriotis, V., Psycharis, Y. (2014). "Between equity, efficiency and redistribution: An analysis of revealed allocation criteria of regional public investment in Greece". European urban and regional studies, 21(4), 445-462.

Moreno, R., López-Bazo, E. (2007). Returns to local and transport infrastructure under regional spillovers. International Regional Science Review, 30(1), 47-71.

Morrison, C. J., Schwartz, A. E. (1996). "Public infrastructure, private input demand, and economic performance in New England manufacturing". Journal of Business \& Economic Statistics, 14(1), 91-101.

Munnell, A., with the assistance of Cook, L. (1990) "How Does Public Infrastructure Affect Regional Economic Performance?" New England Economic Review, Federal Reserve Bank of Boston, September/October, 11-32.

Nadiri, M. I., Mamuneas, T. P. (1994). "Infrastructure and public R\&D investments, and the growth of factor productivity in US manufacturing industries". National Bureau of Economic Research, No. w4845.

Percoco, M. (2016). Highways, local economic structure and urban development, Journal of Economic Geography, 16, 1035-1054.

Pereira, A., M., Andraz, J.M. (2006). "Public investment in transportation infrastructures and regional asymmetries in Portugal”. Annals of Regional Science, 40, 803-817.

Rodríguez-Pose, A., Psycharis, Y., Tselios, V. (2012), "Public investment and regional growth and convergence: Evidence from Greece”. Papers in Regional Science, 91: 543-568.

Sala-i-Martin, X. (1996) "Regional cohesion: Evidence and theories of regional growth and convergence", European Economic Review, 40, 1325-1352.

$\mathrm{Xu}, \mathrm{H}$. , Nakajima, K. (2017). Highways and industrial development in the peripheral regions of China, Papers in Regional Science, 96, 325-356.

Yamano, N., Ohkawara, T. (2000) "The regional allocation of public investment: Efficiency or equity?” Journal of Regional Science, vol 40:2, 205-229.

Yu, N., De Jong, M., Storm, S., Mi, J. (2013). Spatial spillovers effects of transport infrastructure: evidence from Chinese regions. Journal of Transport Geography, 28, 56-66 


\section{Figures}

Figure 1. Evolution of transport investment in Spain, 1980-2008 (thousands of constant euros, 2000)

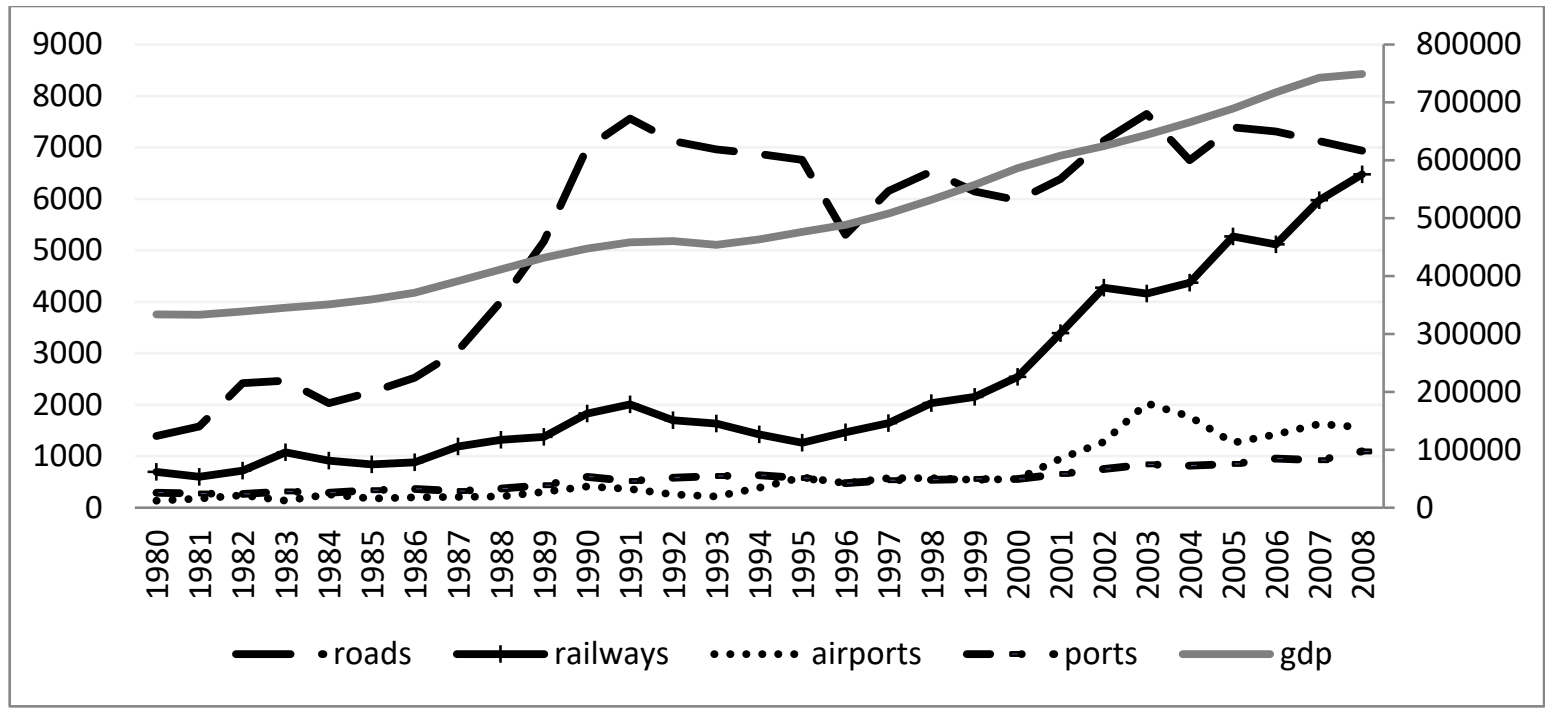

Source: Own elaboration based on data on Instituto Valenciano de Investigaciones Económicas (IVIE) and Instituto Nacional de Estadística (INE)

Figure 2. Distribution of network investment in 1980 (left) and 2008 (right) at NUTS-3

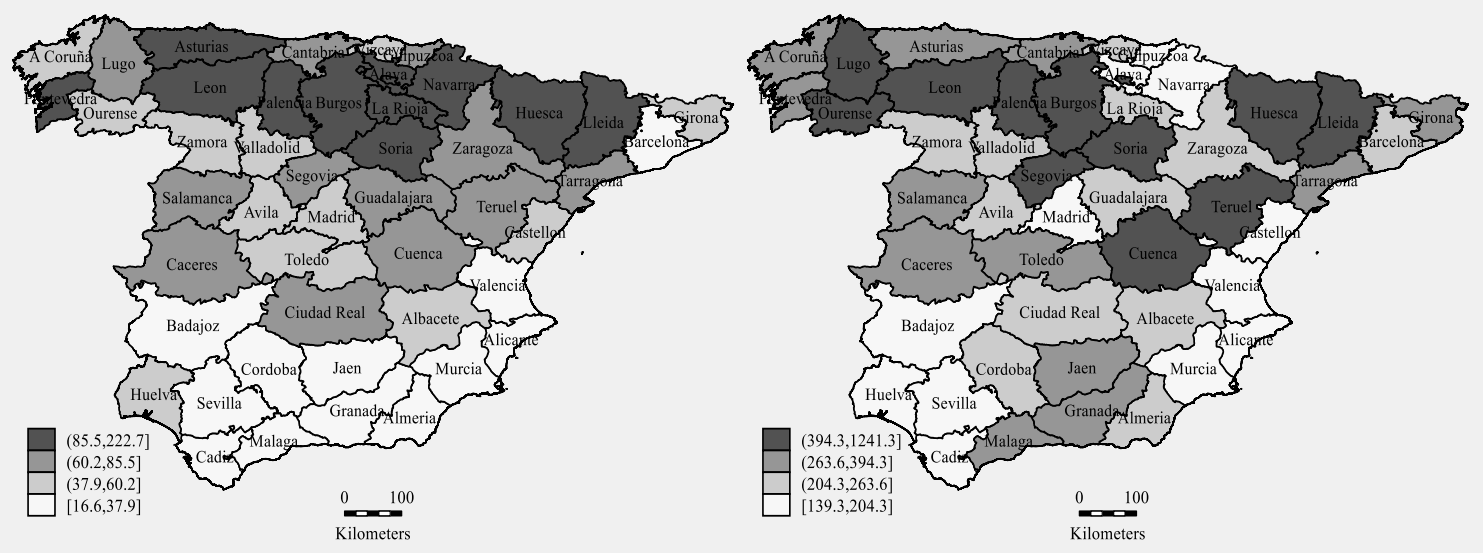

Source: Own elaboration based on IVIE 
Figure 3. Distribution of single investment in 1980 (left) and 2008 (right) at NUTS-3
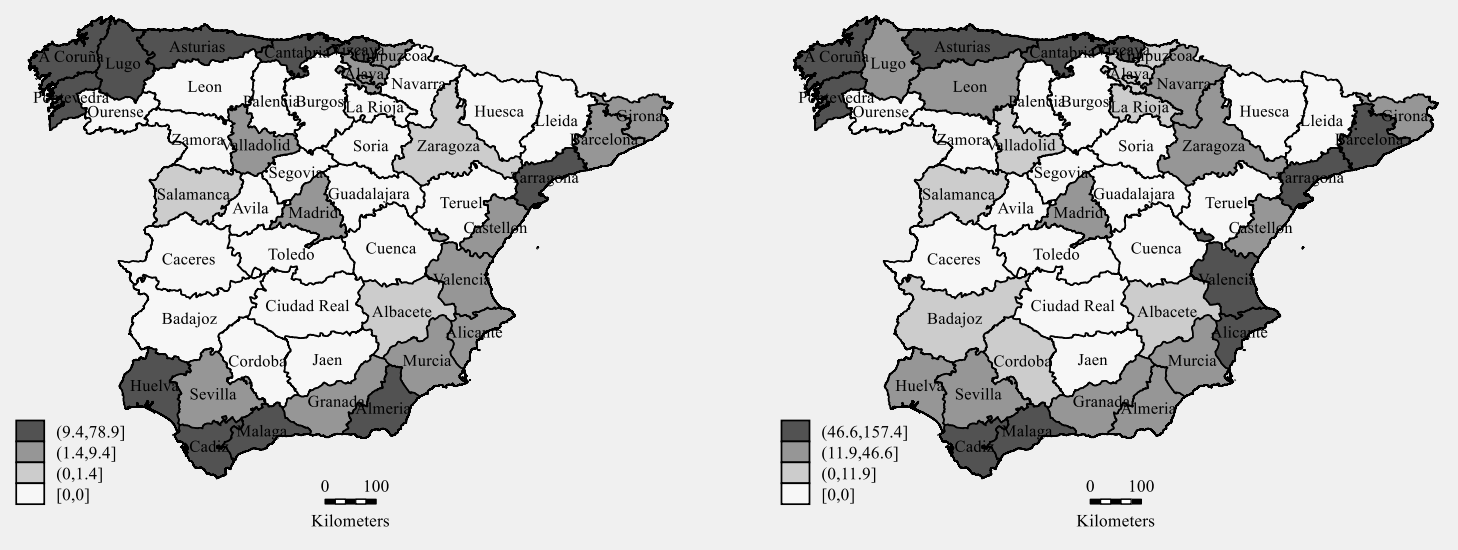

Source: Own calculations based on IVIE

Figure 4- Distribution of per capita GDP among regions, years 1980-1990-2000-2008
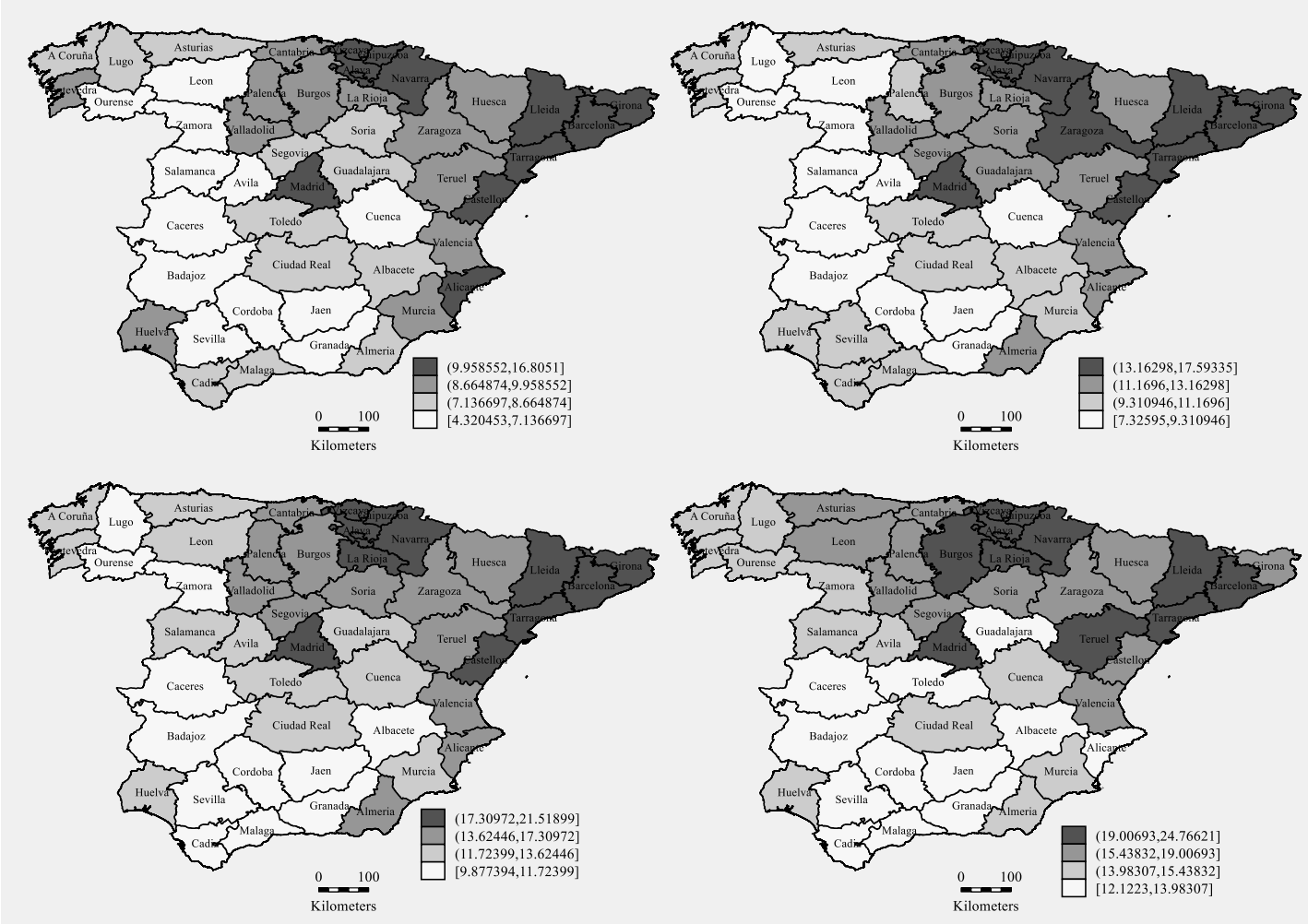

Source: Own elaboration based on INE 
Figure 5- Distribution of per capita GDP growth among regions, periods (90-80) (00-90) (09-99)

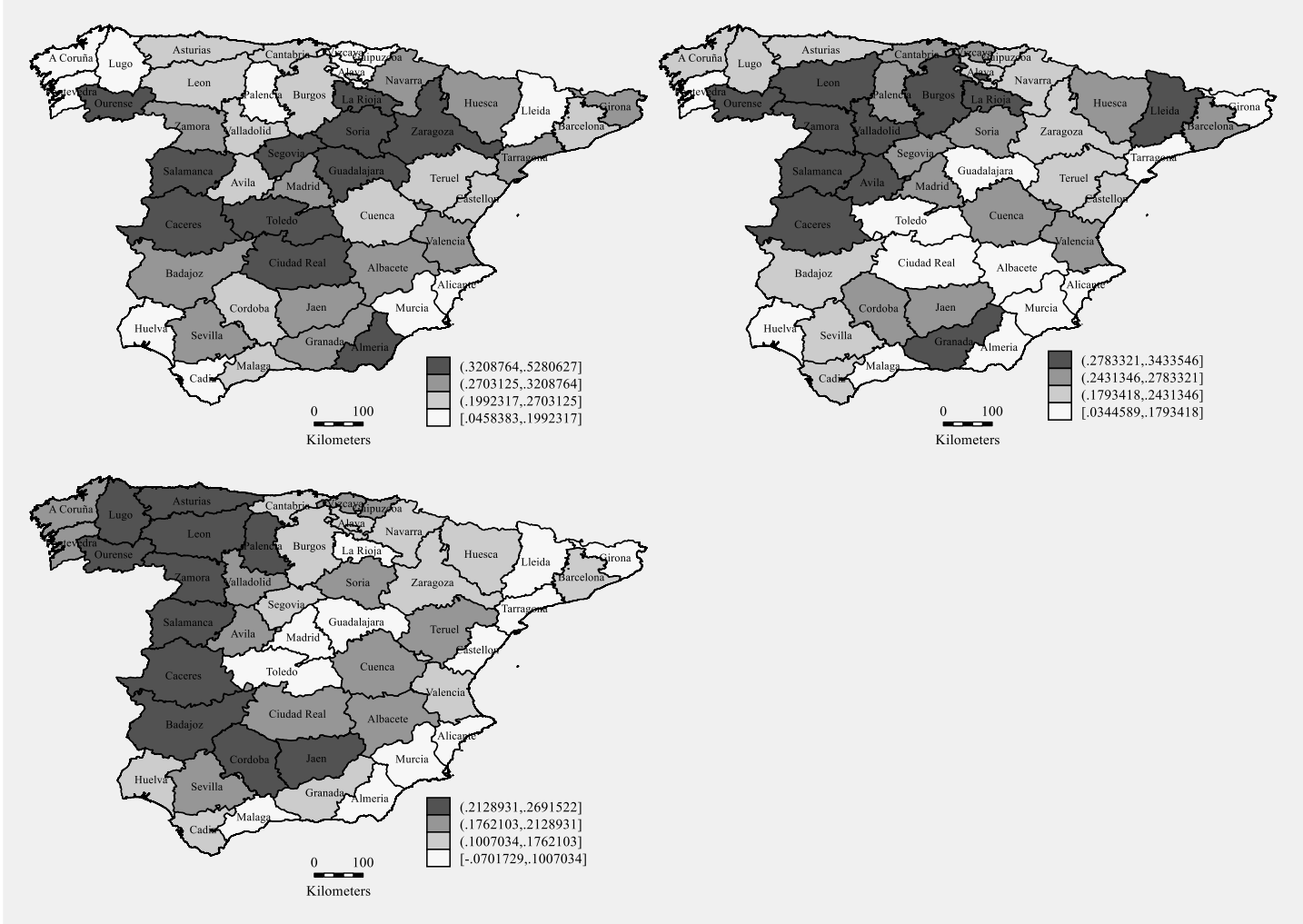

Source: Own calculations based on INE

Figure 6- Relationship between the average annual growth rate of per capita GDP and the initial level of output.

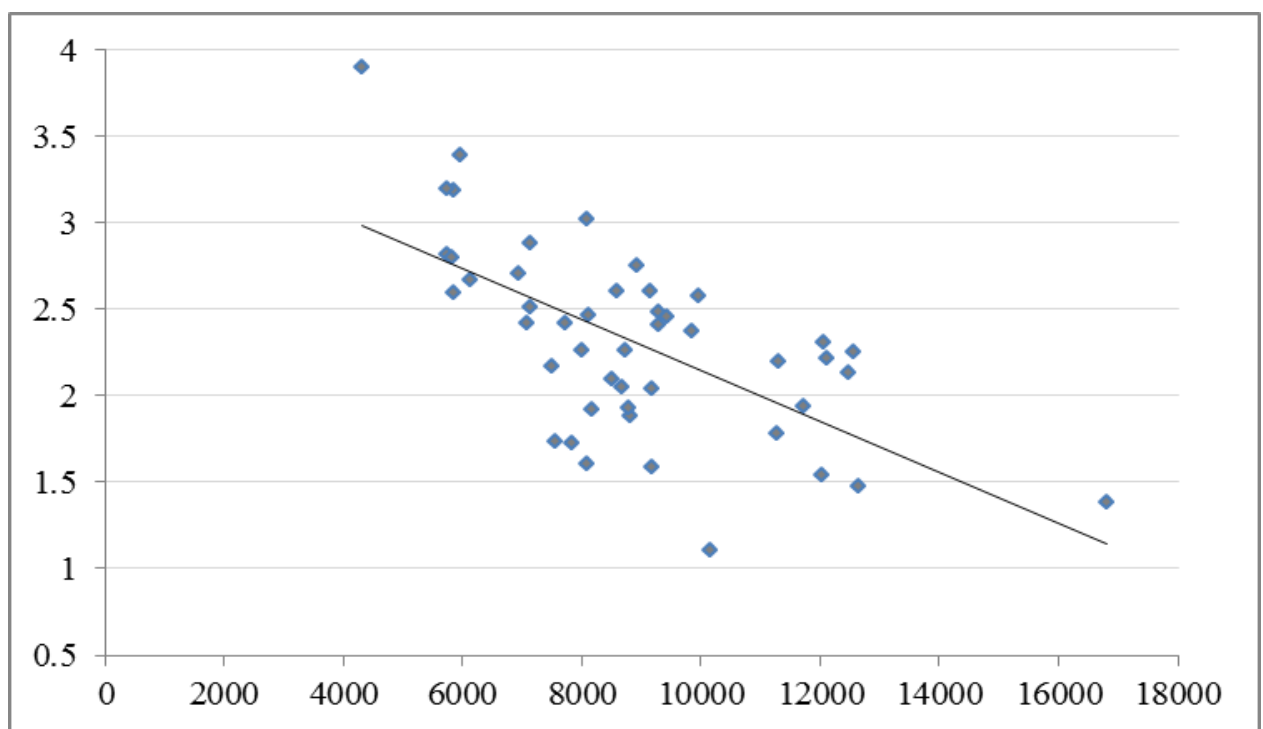

Source: Own elaboration based on INE 
Tables

Table 1- Annual growth rate, descriptive statistics

\begin{tabular}{|c|c|c|c|c|c|c|c|c|}
\hline Province & mean & $\min$ & $\operatorname{Max}$ & range & $\mathrm{p} 25$ & p75 & sd & $\mathrm{cv}$ \\
\hline A Coruña & 2.05 & -1.98 & 7.82 & 9.80 & 0.78 & 3.20 & 2.16 & 1.05 \\
\hline Alacant & 1.11 & -2.98 & 6.42 & 9.41 & -0.76 & 3.30 & 2.48 & 2.24 \\
\hline Albacete & 2.17 & -7.36 & 7.25 & 14.60 & 0.86 & 3.24 & 3.44 & 1.59 \\
\hline Almería & 2.10 & -3.27 & 10.34 & 13.61 & -0.76 & 4.35 & 3.60 & 1.71 \\
\hline Alaba & 1.38 & -8.08 & 4.96 & 13.04 & 0.40 & 3.39 & 2.82 & 2.04 \\
\hline Asturias & 2.46 & -2.76 & 5.80 & 8.55 & 1.31 & 3.92 & 1.85 & 0.75 \\
\hline Ávila & 2.71 & -8.09 & 8.64 & 16.73 & 1.70 & 4.83 & 3.74 & 1.38 \\
\hline Badajoz & 2.82 & -2.99 & 9.20 & 12.19 & 0.86 & 3.96 & 2.82 & 1.00 \\
\hline Barcelona & 2.19 & -2.48 & 6.50 & 8.98 & 0.56 & 3.59 & 2.50 & 1.14 \\
\hline Bizkaia & 2.22 & -1.49 & 7.01 & 8.50 & 0.11 & 3.46 & 2.21 & 1.00 \\
\hline Burgos & 2.58 & -4.07 & 9.51 & 13.58 & 1.60 & 3.77 & 2.83 & 1.10 \\
\hline Cádiz & 3.90 & -2.45 & 20.83 & 23.28 & 1.71 & 4.63 & 4.41 & 1.13 \\
\hline Cantabria & 1.92 & -3.78 & 7.36 & 11.14 & 0.22 & 3.47 & 2.73 & 1.42 \\
\hline Castelló & 2.04 & -4.84 & 10.26 & 15.10 & 0.51 & 3.07 & 2.86 & 1.40 \\
\hline Ciudad Real & 1.78 & -2.75 & 8.31 & 11.07 & 0.05 & 4.07 & 2.68 & 1.51 \\
\hline Cuenca & 2.42 & -3.94 & 9.16 & 13.10 & 1.14 & 3.66 & 2.59 & 1.07 \\
\hline Cáceres & 2.67 & -4.11 & 10.90 & 15.01 & 0.62 & 4.05 & 3.32 & 1.24 \\
\hline Córdoba & 2.51 & -8.19 & 8.58 & 16.77 & 1.98 & 4.07 & 3.77 & 1.50 \\
\hline Gipuzkoa & 2.25 & -5.13 & 6.82 & 11.95 & 0.36 & 4.43 & 2.75 & 1.22 \\
\hline Girona & 1.55 & -3.45 & 9.86 & 13.31 & -0.96 & 3.46 & 2.87 & 1.85 \\
\hline Granada & 2.60 & -5.87 & 8.43 & 14.30 & 1.41 & 3.92 & 2.56 & 0.98 \\
\hline Guadalajara & 1.61 & -5.07 & 17.94 & 23.01 & -1.29 & 2.02 & 5.17 & 3.21 \\
\hline Huelva & 1.89 & -6.16 & 10.26 & 16.42 & -0.65 & 3.92 & 3.70 & 1.96 \\
\hline Huesca & 2.49 & -9.91 & 12.66 & 22.57 & 1.41 & 4.11 & 4.32 & 1.74 \\
\hline Jaén & 2.80 & -8.87 & 11.80 & 20.67 & 0.49 & 4.43 & 4.55 & 1.62 \\
\hline La Rioja & 2.75 & -6.15 & 15.94 & 22.09 & 1.29 & 3.80 & 3.55 & 1.29 \\
\hline León & 2.88 & -1.28 & 9.02 & 10.30 & 1.55 & 4.38 & 2.49 & 0.86 \\
\hline Lleida & 1.94 & -2.80 & 6.17 & 8.97 & 0.70 & 3.42 & 2.25 & 1.16 \\
\hline Lugo & 2.26 & -8.65 & 9.67 & 18.32 & 1.30 & 3.80 & 3.49 & 1.55 \\
\hline Madrid & 2.31 & -2.05 & 8.14 & 10.19 & 0.90 & 3.72 & 2.32 & 1.00 \\
\hline Murcia & 1.74 & -2.79 & 7.49 & 10.28 & 0.61 & 2.79 & 2.30 & 1.32 \\
\hline Málaga & 1.59 & -3.47 & 5.96 & 9.43 & 0.19 & 3.14 & 2.28 & 1.44 \\
\hline Navarra & 2.13 & -2.20 & 9.16 & 11.37 & 1.32 & 2.72 & 2.62 & 1.23 \\
\hline Orense & 3.19 & -4.77 & 10.66 & 15.43 & 1.87 & 4.22 & 2.88 & 0.90 \\
\hline Palencia & 2.41 & -9.58 & 13.87 & 23.45 & -0.07 & 4.26 & 4.80 & 1.99 \\
\hline Pontevedra & 1.93 & -2.57 & 5.95 & 8.52 & 0.69 & 3.40 & 2.14 & 1.11 \\
\hline Salamanca & 3.39 & -6.31 & 8.08 & 14.39 & 1.63 & 5.54 & 3.14 & 0.93 \\
\hline Segovia & 2.60 & -5.33 & 11.75 & 17.08 & 0.66 & 4.50 & 3.61 & 1.39 \\
\hline Sevilla & 2.42 & -6.50 & 7.68 & 14.18 & 1.09 & 3.91 & 3.06 & 1.26 \\
\hline
\end{tabular}




\begin{tabular}{lcccccccc} 
Soria & 3.03 & -6.88 & 10.75 & 17.63 & 0.84 & 5.03 & 3.75 & 1.24 \\
Tarragona & 1.48 & -3.90 & 9.83 & 13.73 & -0.92 & 3.62 & 3.08 & 2.08 \\
Teruel & 2.37 & -19.37 & 14.10 & 33.46 & 0.10 & 5.03 & 5.88 & 2.48 \\
Toledo & 1.72 & -9.13 & 12.18 & 21.31 & 0.24 & 2.83 & 3.97 & 2.31 \\
València & 2.27 & -3.61 & 6.25 & 9.87 & 1.13 & 4.06 & 2.25 & 0.99 \\
Valladolid & 2.46 & -6.79 & 6.66 & 13.45 & 1.43 & 4.62 & 2.76 & 1.12 \\
Zamora & 3.20 & -10.49 & 13.21 & 23.70 & 2.17 & 5.02 & 4.18 & 1.31 \\
Zaragoza & 2.61 & -2.58 & 7.74 & 10.32 & 1.74 & 3.83 & 2.39 & 0.92 \\
Total & 2.32 & -19.37 & 20.83 & 40.20 & 0.71 & 3.91 & 3.25 & 1.40 \\
\hline
\end{tabular}

Source: Own calculations based on INE 
Table 2- Disaggregation of capital stock, mean values (thousands of constant euros, 2000)

\begin{tabular}{|c|c|c|c|c|}
\hline Province & Roads & Railways & Airports & Ports \\
\hline A Coruña & 1,172 & 114 & 106 & 172 \\
\hline Alacant & 876 & 52 & 47 & 57 \\
\hline Albacete & 1,959 & 183 & 3 & 0 \\
\hline Almeria & 1,790 & 50 & 41 & 126 \\
\hline Alaba & 2,246 & 35 & 84 & 0 \\
\hline Asturias & 2,094 & 176 & 14 & 87 \\
\hline Avila & 2,744 & 108 & 0 & 0 \\
\hline Badajoz & 1,678 & 70 & 6 & 0 \\
\hline Barcelona & 741 & 276 & 46 & 18 \\
\hline Bizkaia & 1,547 & 118 & 63 & 76 \\
\hline Burgos & 2,371 & 94 & 0 & 0 \\
\hline Cadiz & 2,282 & 88 & 0 & 0 \\
\hline Cantabria & 885 & 64 & 10 & 90 \\
\hline Castello & 2,326 & 112 & 50 & 97 \\
\hline $\begin{array}{l}\text { Ciudad } \\
\text { Real }\end{array}$ & 1,480 & 381 & 0 & 94 \\
\hline Cuenca & 1,714 & 424 & 0 & 0 \\
\hline Caceres & 1,289 & 540 & 3 & 0 \\
\hline Cordoba & 4,044 & 69 & 0 & 0 \\
\hline Gipuzkoa & 2,022 & 138 & 14 & 125 \\
\hline Girona & 1,621 & 126 & 77 & 80 \\
\hline Granada & 1,581 & 34 & 11 & 37 \\
\hline Guadalajara & 3,732 & 57 & 0 & 0 \\
\hline Huelva & 1,643 & 83 & 0 & 103 \\
\hline Huesca & 3,660 & 166 & 0 & 0 \\
\hline Jaen & 1,733 & 48 & 0 & 0 \\
\hline La Rioja & 1,500 & 48 & 0 & 0 \\
\hline Leon & 2,456 & 88 & 0 & 0 \\
\hline Lleida & 2,942 & 133 & 0 & 0 \\
\hline Lugo & 3,240 & 57 & 0 & 131 \\
\hline Madrid & 637 & 360 & 98 & 0 \\
\hline Murcia & 1,215 & 92 & 112 & 74 \\
\hline Malaga & 992 & 42 & 2 & 42 \\
\hline Navarra & 2,297 & 76 & 15 & 0 \\
\hline Ourense & 2,413 & 41 & 0 & 0 \\
\hline Palencia & 2,841 & 216 & 0 & 0 \\
\hline Pontevedra & 1,266 & 91 & 29 & 79 \\
\hline Salamanca & 1,913 & 66 & 16 & 0 \\
\hline Segovia & 2,819 & 96 & 0 & 0 \\
\hline
\end{tabular}




\begin{tabular}{lcccc} 
Sevilla & 1,091 & 178 & 69 & 17 \\
Soria & 4,978 & 243 & 0 & 0 \\
Tarragona & 1,549 & 312 & 15 & 103 \\
Teruel & 4,109 & 140 & 0 & 0 \\
Toledo & 1,953 & 246 & 0 & 0 \\
Valencia & 1,035 & 295 & 23 & 22 \\
Valladolid & 1,541 & 46 & 20 & 0 \\
Zamora & 3,451 & 67 & 0 & 0 \\
Zaragoza & 1,225 & 189 & 20 & 0 \\
Total & 2,057 & 143 & 21 & 35 \\
\hline
\end{tabular}

Source: Own calculations based on IVIE 
Table 3. Estimation results of Absolute Convergence (bias-corrected fixed effects) Dependent variable is growth of GDP per capita

\begin{tabular}{lccc}
\hline VARIABLES & W_contiguity & W_distance & W_nearestn \\
\hline Gdp & -8.339 & -8.903 & -8.778 \\
& $(1.286)^{* * *}$ & $(1.310)^{* * *}$ & $(1.271)^{* * *}$ \\
$\mathrm{~W}^{*} \mathrm{Gdp}$ & 8.120 & 8.663 & 8.631 \\
& $(1.331)^{* * *}$ & $(1.355)^{* * *}$ & $(1.313)^{* * *}$ \\
$\mathrm{~W}^{*} \Delta G D P_{i t+1, t}$ & 0.411 & 0.450 & 0.596 \\
& $(0.030)^{* * *}$ & $(0.031)^{* * *}$ & $(0.030)^{* * *}$ \\
$\sigma_{\epsilon}^{2}$ & 8.723 & 8.714 & 8.175 \\
& $(0.351)^{* * *}$ & $(0.350)^{* * *}$ & $(0.328)^{* * *}$ \\
& & & \\
Spatial specific effects & YES & YES & YES \\
Observations & 1,269 & 1,269 & 1,269 \\
R-squared & 0.016 & 0.017 & 0.018 \\
Log-likelihood & $-3,202.55$ & $-3,198.97$ & $-3,161.12$ \\
\hline
\end{tabular}

Standard errors in parentheses

$* * * \mathrm{p}<0.01, * * \mathrm{p}<0.05, * \mathrm{p}<0.1$

Table 4. Absolute Convergence, the direct and indirect effects of the explanatory variable Dependent variable is annual growth of GDP per capita

\begin{tabular}{lccc}
\hline VARIABLES & W_contiguity & W_distance & W_nearestn \\
\hline \multirow{3}{*}{ Gdp Direct effect } & & & \\
& -7.828 & -8.459 & -8.501 \\
& $(1.015)^{* * *}$ & $(1.048)^{* * *}$ & $(1.038)^{* * *}$ \\
Indirect effect & 7.502 & 8.079 & 8.212 \\
& $(1.272)^{* * *}$ & $(1.329)^{* * *}$ & $(1.501)^{* * *}$ \\
Total effect & -0.326 & -0.381 & -0.288 \\
& $(0.740)$ & $(0.781)$ & $(1.039)$ \\
\hline
\end{tabular}

Standard errors in parentheses

$* * * \mathrm{p}<0.01, * * \mathrm{p}<0.05, * \mathrm{p}<0.1$ 
Table 5. Estimation results of Conditional Convergence including infrastructure stock (biascorrected fixed effects)

Dependent variable is growth of GDP per capita

\begin{tabular}{|c|c|c|c|}
\hline VARIABLES & W_contiguity & W_distance & W_nearestn \\
\hline Gdp & $\begin{array}{c}-11.7543 \\
(1.476)^{* * *}\end{array}$ & $\begin{array}{c}-12.1617 \\
(1.480)^{* * *}\end{array}$ & $\begin{array}{c}-12.0172 \\
(1.452)^{* * *}\end{array}$ \\
\hline Roads & $\begin{array}{c}1.8369 \\
(0.635)^{* * *}\end{array}$ & $\begin{array}{c}2.0710 \\
(0.639) * * *\end{array}$ & $\begin{array}{c}2.0143 \\
(0.655)^{* * *}\end{array}$ \\
\hline Railways & $\begin{array}{c}-0.1783 \\
(0.180)\end{array}$ & $\begin{array}{l}-0.1129 \\
(0.175)\end{array}$ & $\begin{array}{c}-0.1158 \\
(0.172)\end{array}$ \\
\hline Airports & $\begin{array}{r}-0.0425 \\
(0.067)\end{array}$ & $\begin{array}{c}-0.0545 \\
(0.067)\end{array}$ & $\begin{array}{r}-0.0398 \\
(0.066)\end{array}$ \\
\hline Ports & $\begin{array}{c}-0.7322 \\
(0.289)^{* *}\end{array}$ & $\begin{array}{c}-0.8827 \\
(0.284)^{* * *}\end{array}$ & $\begin{array}{c}-0.8164 \\
(0.277)^{* * *}\end{array}$ \\
\hline $\mathrm{W}^{*} \mathrm{Gdp}$ & $\begin{array}{c}8.4905 \\
(1.859)^{* * *}\end{array}$ & $\begin{array}{c}8.8920 \\
(1.884)^{* * *}\end{array}$ & $\begin{array}{c}10.2465 \\
(2.046)^{* * *}\end{array}$ \\
\hline W*Roads & $\begin{array}{r}-0.8899 \\
(0.880)\end{array}$ & $\begin{array}{c}-0.9513 \\
(0.891)\end{array}$ & $\begin{array}{l}-2.0047 \\
(1.120)^{*}\end{array}$ \\
\hline W*Railways & $\begin{array}{l}0.1407 \\
(0.398)\end{array}$ & $\begin{array}{l}0.0676 \\
(0.438)\end{array}$ & $\begin{array}{c}-0.2185 \\
(0.594)\end{array}$ \\
\hline $\mathrm{W}^{*}$ Airports & $\begin{array}{c}-0.0782 \\
(0.138)\end{array}$ & $\begin{array}{l}0.0236 \\
(0.159)\end{array}$ & $\begin{array}{l}0.0658 \\
(0.154)\end{array}$ \\
\hline $\mathrm{W}^{*}$ Ports & $\begin{array}{c}1.5581 \\
(0.667)^{* *}\end{array}$ & $\begin{array}{c}1.3586 \\
(0.686)^{* *}\end{array}$ & $\begin{array}{c}2.4765 \\
(1.098)^{* *}\end{array}$ \\
\hline $\mathrm{W}^{*} \Delta G D P_{i t+1, t}$ & $\begin{array}{c}0.4142 \\
(0.030)^{* * *}\end{array}$ & $\begin{array}{c}0.4456 \\
(0.031)^{* * *}\end{array}$ & $\begin{array}{c}0.5893 \\
(0.034)^{* * *}\end{array}$ \\
\hline$\sigma_{\epsilon}^{2}$ & $\begin{array}{c}8.5427 \\
(0.344)^{* * *}\end{array}$ & $\begin{array}{c}8.5419 \\
(0.343)^{* * *}\end{array}$ & $\begin{array}{c}8.0254 \\
(0.322)^{* * *}\end{array}$ \\
\hline Spatial specific effects & YES & YES & YES \\
\hline Observations & 1,269 & 1,269 & 1,269 \\
\hline R-squared & 0.41 & 0.40 & 0.46 \\
\hline Log-likelihood & -3188.50 & -3185.81 & -3148.74 \\
\hline
\end{tabular}

Standard errors in parentheses

$* * * \mathrm{p}<0.01, * * \mathrm{p}<0.05, * \mathrm{p}<0.1$ 
Table 6. Conditional Convergence and the direct and indirect effects of the four types of transport infrastructure stock

Dependent variable is annual growth of GDP per capita

\begin{tabular}{|c|c|c|c|c|}
\hline \multicolumn{2}{|c|}{ VARIABLES } & \multirow{3}{*}{$\begin{array}{c}\text { W_contiguity } \\
-11.3415 \\
(1.196)^{* * *}\end{array}$} & \multirow{3}{*}{$\begin{array}{c}\text { W_distance } \\
-11.8200 \\
(1.207)^{* * *}\end{array}$} & \multirow{3}{*}{$\begin{array}{c}\text { W_nearestn } \\
-11.7454 \\
(1.197)^{* * *}\end{array}$} \\
\hline Gdp & Direct effect & & & \\
\hline & & & & \\
\hline & Indirect effect & 6.1955 & 6.3821 & 8.1707 \\
\hline & & $(2.402)^{* * *}$ & $(2.578) * *$ & $(3.877)^{* *}$ \\
\hline & Total effect & -5.1460 & -5.4379 & -3.5747 \\
\hline & & $(2.386)^{* *}$ & $(2.541)^{* *}$ & (3.832) \\
\hline \multirow{6}{*}{ Roads } & Direct effect & 1.8511 & 2.1007 & 1.9767 \\
\hline & & $(0.684)^{* * *}$ & $(0.693)^{* * *}$ & $(0.713) * * *$ \\
\hline & Indirect effect & -0.4887 & -0.3409 & -2.4542 \\
\hline & & $(1.274)$ & (1.376) & $(2.437)$ \\
\hline & Total effect & 1.3624 & 1.7598 & -0.4775 \\
\hline & & (1.335) & $(1.428)$ & $(2.463)$ \\
\hline \multirow[t]{6}{*}{ Railways } & Direct effect & -0.1646 & -0.1048 & -0.1353 \\
\hline & & $(0.225)$ & $(0.210)$ & $(0.214)$ \\
\hline & Indirect effect & 0.0406 & -0.0409 & -0.8262 \\
\hline & & $(0.709)$ & $(0.778)$ & (1.488) \\
\hline & Total effect & -0.1240 & -0.1457 & -0.9615 \\
\hline & & $(0.879)$ & $(0.915)$ & (1.632) \\
\hline \multirow[t]{6}{*}{ Airports } & Direct effect & -0.0548 & -0.0559 & -0.0367 \\
\hline & & $(0.070)$ & $(0.070)$ & $(0.069)$ \\
\hline & Indirect effect & -0.1681 & -0.0164 & 0.0901 \\
\hline & & $(0.207)$ & $(0.255)$ & $(0.352)$ \\
\hline & Total effect & -0.2229 & -0.0723 & 0.0534 \\
\hline & & $(0.248)$ & $(0.294)$ & $(0.392)$ \\
\hline \multirow[t]{6}{*}{ Ports } & Direct effect & -0.5399 & -0.7404 & -0.5916 \\
\hline & & $(0.312)^{*}$ & $(0.291)^{* *}$ & $(0.295)^{* *}$ \\
\hline & Indirect effect & 2.1573 & 1.7830 & 5.1348 \\
\hline & & $(1.198)^{*}$ & (1.302) & $(2.933)^{*}$ \\
\hline & Total effect & 1.6174 & 1.0426 & 4.5432 \\
\hline & & (1.384) & (1.439) & $(3.082)$ \\
\hline
\end{tabular}

Standard errors in parentheses

$* * * \mathrm{p}<0.01, * * \mathrm{p}<0.05, * \mathrm{p}<0.1$ 
Table 7. Estimation results of the determinants of transport infrastructure investment Dependent variable is annual growth of stock in transport infrastructure

\begin{tabular}{lc}
\hline VARIABLES & $\Delta$ transport \\
\hline$\Delta$ transport(-1) & -0.0426 \\
& $(0.062)$ \\
Efficiency & -0.2547 \\
& $(0.105)^{* *}$ \\
Redistribution & 0.3632 \\
& $(0.090)^{* * *}$ \\
Equity & -0.4698 \\
& $(0.107)^{* * *}$ \\
Partisan strongholds & -0.0009 \\
& $(0.005)$ \\
Political congruence & -0.0085 \\
& $(0.035)$ \\
& \\
Observations & 1,222 \\
Number of regions & 47 \\
Time dummy variables & Yes \\
Number of instruments & 108 \\
Hansen Test Overid (p-value) & 1 \\
Difference-in-Hansen (p-value) & 1 \\
AR(1) (p-value) & 0.000 \\
AR(2) (p-value) & 0.286 \\
\hline
\end{tabular}

Robust standard errors in parentheses

$* * * \mathrm{p}<0.01, * * \mathrm{p}<0.05, * \mathrm{p}<0.1$ 